\title{
RESEARCH ON THE EFFECTS OF JOB SATISFACTION ON ORGANIZATIONAL TRUST AND ORGANIZATIONAL CITIZENSHIP IN HEALTH WORKERS: A CASE STUDY OF UNIVERSITY HOSPITALS*
}

\author{
DOI: 10.17261/Pressacademia.2020.1285 \\ JMML- V.7-ISS.3-2020(3)-p.124-142
}

\section{Nurgul Erdal ${ }^{1}$, Erkut Altindag ${ }^{2}$}

${ }^{1}$ Istanbul University, Cerrahpasa Medical School, Hospital of School of Medicine, Istanbul, Turkey. nurgul.erdal@istanbul.edu.tr, ORCID: 0000-0002-2961-3906

${ }^{2}$ Beykent University, Maslak Campus, Istanbul, Turkey. erkutaltindag@beykent.edu.tr, ORCID: 0000-0003-0173-0454

Date Received: June 17, 2020

Date Accepted: September 6, 2020

\section{To cite this document}

Erdal, N., Altindag, E., (2020). Research on the effects of job satisfaction on organizational trust and organizational citizenship in health workers: a case study of university hospitals. Journal of Management, Marketing and Logistics (JMML), V.7(3), p.124-142.

Permanent link to this document: http://doi.org/10.17261/Pressacademia.2020.1285

Copyright: Published by PressAcademia and limited licensed re-use rights only.

\begin{abstract}
Purpose- The aim of this study is to examine the impact of organizational trust and organizational citizenship behavior on job satisfaction in healthcare workers. This study is also intended to be a role model for service businesses.

Methodology- To analyze this relationship, research was conducted on 945 people working in university hospitals. This includes the relationship of the lower dimensions of job satisfaction, which is the research dependent variable, to the lower dimensions of other independent variables. Findings- The lower dimensions of trust in a manager and trust in an institution and workload are all moderately related to both dependent variable sizes. The salary and promotion dependent variable turns out to be unaffected by the lower dimension of trust in a manager. The lower dimensions of taking on the workload and feeling of belonging negatively affect job satisfaction in terms of salary and promotion. Trust in the institution and disciplined work has had a direct and positive effect on salary and promotion. The second dependent variable, the feeling of job satisfaction, is directly and positively affected by trust in a manager, trust in an institution, and disciplined work sub dimensions. Organizational trust has been studied as an intermediary variable; as such, no relationship has been found between the sub dimensions of organizational citizenship behavior and the sub dimensions of job satisfaction. In addition, organizational citizenship and job satisfaction between the mediated effects of organizational trust has been examined, but no significant relationship has been found.

Conclusion- This study develops a new model of the hospital management's hospitals interaction experience. This new model fills a research gap by providing an empirical study of the repeated hospital management
\end{abstract}

Keywords: health employee, organizational citizenship, organizational trust, job satisfaction, hospital management. JEL Codes: M10, M11, M12

*This study is produced from a PhD Thesis titled "Research on the Effects of Job Satisfaction on Organizational Trust and Organizational Citizenship in Health Workers: A Case Study of University Hospitals", Beykent University, Graduate School of Social Sciences.

\section{INTRODUCTION}

University hospitals, which are health enterprises operating in an environment of globalization and extreme competition, have a wide range of responsibilities. In addition to providing regional health care, they typically lead an entire country and even the world. University hospitals' other important responsibilities include education and research (Filiz and Bardakçi, 2020). The changing demands of our age, the development of technology, the easing of access to information, new management forms, etc. affects the quality of the service provided but are typically insufficient (Artar et al., 2019). The focus has, thus, been on how businesses should act and be managed strategically in order to achieve a competitive advantage (Zengin and Kaygın, 2019). In order to achieve maximum efficiency and best performance in organizations, it is necessary to reduce and eliminate factors that cause inefficiency. Organizational trust does not encompass a single individual or a specific team, i.e., it is a whole that 
encompasses systems involving multiple actors (Verburg et al., 2018). When employees do their best to succeed and devote themselves to work, the result is an effective and efficient organization. This happens thanks to employees who develop organizational citizenship behavior (Yorgancıoğlu Tarcan et al., 2019). Absenteeism will increase, motivation and performance among employees will decrease, and patient quality of care will decrease, as the turnover rate in low organizational security will remain high (Aydan and Kaya, 2018). As with all service enterprises, health enterprises face problems such as waste, lack of personnel, excessive workload, lack of trained managers, and employee dissatisfaction. In order to overcome these drawbacks, employees who trust each other, their managers, and their organizations typically demonstrate organizational citizenship behavior and job satisfaction.

\section{LITERATURE REVIEW}

\subsection{Organizational Trust (OT)}

The majority of researchers have stated that trust is important in individual and group behavior as well as in administrative, economic, social, and political behavior and cannot be fully defined (Hosmer, 1995). The most important indicator in organizational management is trust (Mishra and Morrissey, 1990). The success of businesses and the constructive relationship of employees and managers are achieved through organizational trust (Önder and Yavuz, 2019). Employees' reliance on their institutions, colleagues, and managers' increases communication, assistance, business success, teamwork, employee performance, and organizational identification (Memduhoğlu and Zengin, 2017). Confidence has been studied in three dimensions: emotionally, cognitively, and behaviorally (Bromiley and Cummings, 1996). The emotional dimension is the intention of the individual to exhibit reliable behavior; the conscious dimension is the intention of the individual's wishes and actions to be compatible with others; the behavioral dimension is the intention not to take advantage of another (Özafşarlioğlu Sakalli, 2015). Organizational trust can be examined in three subheadings: trust in organization; trust in manager; trust in colleagues. Although these dimensions are related, sometimes they may not be related to each other. Members of an organization may not trust the organization while trusting the manager and vice versa (Pars Sener, 2017).

\subsection{Organizational Citizenship Behavior (OCB)}

Organizational citizenship behavior is a voluntary phenomenon of employees, although organizations are not officially defined in the reward system (Karaman and Aylan, 2012). This is a useful form of behavior that is considered to exceed role demands (Supriyanto et al., 2020). Utilizing extra-role behavior, e.g., employees helping their coworkers voluntarily share resources, organization representation, working extra hours without pay, the company is, thus, actively seeking solutions to help maintain respect in the workplace (Parasetio et al., 2017). Businesses that have individuals who develop organizational citizenship behavior typically achieve success (Akinci Tanyıldız and Serin, 2020).Four important factors that will preserve the importance of organizational citizenship behavior in the future. The first of these factors is global competition, organization members, citizenship performance, organizational support, and conscientious initiative. Second, the popularity of team-based organizations will increase the personal support trend of citizenship. The third is downsizing adaptability and willingness to make extra efforts. The fourth is that customer satisfaction is becoming increasingly important (Erdogan and Iraz, 2019). Organ (1977) classified these dimensions as altruism, civic virtue, conscientiousness, civility, and sportsmanship.

\subsection{Job Satisfaction (JS)}

Job satisfaction became popular in the 1930s (Kim et al., 2009). It was first described by Hoppock (1935) and has been recognized as a whole of psychological, physiological, and environmental factors that enable one to say "I am generally satisfied with my work" (Sing, and Onahring, 2019). Vroom (1964) described job satisfaction as emotional orientation and evaluated job satisfaction as an individual's choice against these awards with awards in the working environment. The development of technology and environmental changes in the 1980s brought human capital to the fore. In the 1990s, however, the human factor gained an important overwhelming force in the industry, and human values and philosophical approaches were adopted (Gopinath and Shibu, 2016).Job satisfaction is a feeling that is associated with the future and results from an assessment of expectation and situation (Nam, 2018). It also brings out the inner peace and comfort felt. Positive happiness toward work is defined as "job satisfaction"; negative is defined as "job dissatisfaction" (Jafarova and Sağlam, 2018). The more people and organization harmonize, the easier it is to achieve common goals, which increases employee happiness (Cindiloğlu Demirer, 2019). Factors affecting job satisfaction are as follows: 


\subsubsection{Relationship between Organizational Trust and Job Satisfaction}

Confidence is essential for their personal ability, job satisfaction, and for businesses to sustain long-term activities. If an understanding of mutual trust has developed among the members forming the organization, they are among the highperformance organizations (Çiçek and Şahin Macit, 2016). Sökmen (2019) found a positive and meaningful relationship among ethical leadership, organizational trust, and job satisfaction and a negative and meaningful relationship among ethical leadership, organizational trust, and intention to leave the job. Gider et al. (2019) found that organizational trust has a strong positive correlation over job satisfaction and commitment (Gider et al., 2019). Bil (2018) master's thesis Inan and Çelik (2018) analyzed the job satisfaction relationship with organizational trust with bank employees. According to gender, children, age, and working conditions, job satisfaction was partially accepted, and differentiation according to sector, choice of occupation, wage organizational trust and job satisfaction relationship was accepted (Inan and Çelik, 2018). In his (2018) master's thesis, Demiralp explored the impact of the competence dimension in empowering staff with people working in a public organization on organizational confidence and job satisfaction. The effectiveness dimension was found to be meaningless in strengthening staff for the remaining dimensions. Yanik and Naktiyok (2017) examined the relationship of moral leadership, job satisfaction, organizational commitment, organizational justice, and organizational trust. Üngören et al. (2017) hypothesized that fatalistic beliefs about work accidents negatively affect job satisfaction and organizational confidence. Çiçek and Şahin Macit (2016) revealed the existence of a meaningful and positive relationship between employees' organizational confidence and job satisfaction. Öktem et al. (2016) noted that, in regard to effects on organizational climate, organizational trust, organizational identification, job satisfaction, and intention to quit, organizational climate alone does not affect job satisfaction but affects others (Öktem etal., 2016). Tekingündüz et al., (2015).

In research abroad, Gupta and Singla (2016) found a positive meaningful relationship between job satisfaction and organizational trust in the relationship of organizational change, job satisfaction, and organizational trust with employees (Gupta and Singla, 2016). In 2015, Fard and Karimi ( 2015) conducted research on the structural model between organizational trust and organizational silence of their employees related to job satisfaction and organizational commitment. The results of the study showed that organizational trust has an inverse and meaningful relationship with organizational silence and a positive and meaningful relationship with job satisfaction and organizational commitment. Avram et al. (2015) identified the mediating role of job satisfaction in the relationship between security climate perception and organizational trust, which was found to be a partial mediator in the relationship among job satisfaction, security climate perception, and organizational trust.

H1: Organizational trust has a positive impact on job satisfaction.

In addition, employees often feel mistrust toward their managers for not fulfilling their promises (Artar et al., 2019).

H1a: Trust in a manager has a positive effect on job satisfaction.

Studies with public employees and private-sector employees have shown that public employees tend to be more satisfied with their jobs (Zeffane and Melhem, 2017). The relationship of employees to organizational trust was investigated in the hospitality sector, and a moderately positive relationship was found between trust in manager and job satisfaction; further, a moderately positive relationship was found between trust in colleagues and job satisfaction (Aydin, 2017). Li et al. (2018) exemplified a multilevel model in relation to the job performance of teachers, with teachers and principals in Chinese elementary schools. It also showed the role of mediating job satisfaction and the effects of factors at the school level (partially mediating the positive relationship between organizational trust and job performance). Yausef (2017) explored the direct and indirect relationships between supervisors and employees in the United Arab Emirates and attitudes and dimensions toward job satisfaction, organizational commitment, and organizational change. The results showed that employees in the departments under review were quite satisfied with their supervisor and coworkers, somewhat satisfied with their working conditions and job security, but had low satisfaction with the pay and promotion aspects of the job satisfaction.

H1b: Trust in an organization has a positive effect on job satisfaction.

Studies at home and abroad support the relationship between organization trust and job satisfaction, especially in recent years (examples of studies follow). There is a positive and moderate relationship among organizational trust, trust in managers, trust in colleagues, and trust in stakeholders. When the literature is examined, job satisfaction, and (Gider, 2010; Iscan and Sayin, 2010; Bil, 2018; Çelebi and Tatik, 2019; There is also a positive relationship between organizational trust research in workplaces. Studies show that organizational confidence is a phenomenon closely related to job satisfaction, resulting in changes that positively affect 
an organization such as Performa relationships between organizational citizenship and job satisfaction increase, decrease of discontinuity, and decrease of stress levels (Bil, 2018).

\subsubsection{Relationship between Organizational Citizenship and Job Satisfaction}

Today, employees are considered the most indispensable of business resources. It is necessary for employees to strive for organizational development, as there is global competition and tendency toward consumption. Employees with high organizational citizenship behavior increase job satisfaction, which are also quite difficult to manage (Bismas and Mazumder, 2017). The more organizational citizenship behavior those who work in the organization show, the more their colleagues will be affected by them. As time passes, they begin to behave in the same way as friends (Şehitoğlu and Zehir, 2010).

H2: Organizational citizenship has a positive effect on job satisfaction.

H2a: Undertaking workload has a positive effect on job satisfaction.

H2b: Disciplined work has a positive effect on job satisfaction.

H2c: Feeling of belonging has a positive effect on job satisfaction.

Erdoğdu and Sökmen (2019) found a positive and statistically significant effect of organizational commitment and organizational citizenship behavior on job satisfaction, which is a partial mediating effect of organizational citizenship behavior on the relationship between organizational commitment and job satisfaction. Örücü and Kaçan (2019) found a high level of positive directional relationship between job satisfaction and organizational citizenship behavior, affecting it significantly and positively. Büyükyilmaz (2018) revealed a partially mediated effect of job satisfaction on the relationship between person-organization harmony and organizational citizenship behavior dimensions (altruism, conscientiousness, politeness, sportsmanship, civic virtue [Büyükyilmaz, 2018]). Tokel (2017) found a moderately significant relationship between organizational citizenship behavior and job satisfaction with people working in administrative positions at a university. Büyükyilmaz and Yeğin (2017) identified the existence of positive directional effects on all aspects of both person-organization harmony and job satisfaction and organizational citizenship behavior. Yildiz (2014) found the full mediating role of job satisfaction in the impact of process justice on organizational citizenship behavior. Gunner et al. revealed that organizational citizenship behavior and cynicism have a negative effect on performance and a positive effect on job satisfaction (Topçu et al., 2017).

The research conducted among bank employees in Indonesia found a direct and indirect relationship between organizational citizenship behavior and job satisfaction. It has been proposed to develop human resources in organizations to form a high degree of organizational citizenship behavior (Prasetio, 2017). Yadav and Gupta's 2017 study of the Indian tourism industry found that organizational fairness, job satisfaction, and organizational citizenship behavior were not mediated by organizational trust. Nasra and Heilbrunn (2016) revealed that job satisfaction is mediated between transformational leadership and organizational citizenship. Sawitri et al. (2016) also revealed that organizational citizenship behavior and organizational commitment positively affect job satisfaction. Pouramini and Fayyazi (2015) stated that there is a strong association between job satisfaction and organizational citizenship behavior and that it plays a key role in performance enhancement. The study conducted in the People's Republic of China found that lower dimensions of organizational citizenship behavior positively affect job performance (Anvari et al., 2015). In a study conducted in the Iranian health sector, organizational citizenship behavior was found to have a positive relationship with five sub dimensions. Altruism and civility were found under the individual-directed group, while sportsmanship, civic virtue, and conscientiousness were found low in rulers. In addition, a low positive result was observed in the relationship between organizational citizenship behavior and job satisfaction (Khiabani, 2014).Previous studies also observed a relationship between organizational citizenship behavior and job satisfaction.

\subsubsection{Relationship between Organizational Trust and Organizational Citizenship Behavior}

In order to build employee trust, a structure that facilitates and supports employees' jobs needs to be established (Alev, 2019). The more organizational citizenship behavior those who work in the organization show, the better their colleagues will be affected by such behavior. As time passes, employees typically begin to behave as friends (Şehitoğlu and Zehir, 2010). Organizational citizenship behavior is associated with job satisfaction, organizational commitment, organizational vocalization and silences, organizational trust, motivations, performances, and personal and organizational development of employees. Increasing performance, facilitating management activities, and increasing job satisfaction are among the benefits of organizational citizenship (Harbalioğlu, 2014). 
Ersan (2018) found a positive directional meaningful relationship between organizational trust and organizational citizenship behavior. Yildiz examined the mediating role of positive psychological capital in health care workers in 2019 and supported the mediating role of organizational trust in the relationship of positive psychological capital to organizational citizenship behavior (Yildiz, 2019). Envergil (2018) found the relationship of psychological contract perceptions to organizational trust and organizational citizenship behavior to be moderate. Cankül et al. (2018) found that organizational trust positively affects organizational citizenship behavior and job performance. The study also revealed that organizational citizenship behavior positively affects job performance. Buyukyilmaz and Fidan (2017) revealed that organizational support, organizational trust, and organizational support among organizational citizenship behavior, selflessness, and chivalry have the mediating effect of organizational trust on courtesy and civic virtue. Dede (2017) found that the perception of job insecurity on organizational trust and organizational citizenship behavior is low, while organizational trust and organizational citizenship behavior is high. Akbulut (2017) examined the effect of alienation on organizational trust and organizational citizenship behavior and found that alienation has a meaningful effect on organizational trust and organizational citizenship behavior. Yildiz (2015) showed that positive psychological capital is positively associated with organizational trust and organizational citizenship behavior. The role of organizational trust in the relationship between positive psychological capital and organizational citizenship behavior, which is also the main hypothesis of the study, was supported.

Job characteristics (e.g., job autonomy, skill and diversity of talent, role conflict), work-related attitudes (e.g., job satisfaction, organizational commitment, organizational trust) and civic virtue and sacrifice of university administrators, job satisfaction, organizational commitment, organizational trust and job design, increasing job diversity and job autonomy and organizational citizenship aims to prevent conflicts by offering. Both direct and indirect effects on job autonomy, civic virtue, sacrifice, and the indirect impact of skill diversity on civic virtue and altruism have proven direct and indirect effects (Ababneh and Hackett, 2019). Khalifa and Awad (2018) found a fairly high association in research between organizational justice perception and organizational citizenship behavior. Research on the Nigerian Police Force revealed a meaningful interaction between employee engagement and organizational citizenship behavior. Links to increase the desire for organizational citizenship behavior should be provided, and trust should be established by improving the management positive audit phase at every stage of the organization (Unaam et al., 2018). Mahmoudi et al (2017) and his friends in Iran nurses on organizational justice, organizational commitment, organizational trust, job satisfaction, and organizational citizenship behavior related to the study of organizational justice perceptions, organizational commitment, organizational trust and job satisfaction demonstrated a positive and significant relationship between. In addition, organizational commitment and trust were recognized in the relationship between justice and organizational citizenship in the mediating role model; however, no relationship was observed among job satisfaction, organizational justice, and organizational citizenship behavior.

Singh and Srivastava saw positive association with upper middle and lower managers in the service and manufacturing sector in 2016 in all dimensions of organizational trust and organizational citizenship behavior (Singh and Srivastava, 2016). Organizational justice and organizational citizenship behavior in employees of private banks in Syria in 2014, with Ismail in the relationship between the dimensions of organizational justice (e.g., distribution, procedural, and interactional) on organizational citizenship behavior has a significant positive effect. Similarly, organizational trust has been found to positively influence organizational citizenship behaviors and play a mediating role in their relationship.

\section{DATA AND METHODOLOGY}

\subsection{Purpose and Importance of Research}

The main purpose of this thesis study is to reveal the impact of organizational trust and organizational citizenship on job satisfaction. The health care sector has a comprehensive, in-house workflow and requires health professionals to work together, i.e., employees interact with each other and do the work in a coordinated manner. The important issue here is that individual behaviors should be referred and managed for organizational purposes. Organizational citizenship behavior and organizational citizenship behavior to ensure job satisfaction by creating high individuals and to declare their superiority over other organizations. Many changes have taken place in internal and external environments, and organizations are significantly affected by these changes. It is necessary to regain employees who cannot keep up with the changes that have taken place in an organization's internal and external environments. This study aims to determine the underlying causes of employees' behavior and to correct these behaviors for the benefit of the individual and organization. This information will help managers to determine their own management styles; further, when employees predict what they can do, resource planning is done in a healthier way and resources are best evaluated. Thus, this study aims to provide the highest level of service by satisfying the employees and the patient. 


\subsection{Content and Limits of Research}

The scope and limits of this research consist of the results of the survey scale conducted on the employees of two university hospitals operating in Istanbul, Turkey. The research describes how organizational trust and organizational citizenship behavior have an impact on job satisfaction. The applied method also imposes some restrictions. The sample was conducted with 945 employees at the leading university hospital in Turkey, and this number is suitable for the sample. The acceptability of the findings as a role model for many health care businesses across the country can be considered an important factor.

The main research in Turkey, Istanbul University Medical Faculty, Istanbul University, Cerrahpasa Medical Faculty, Istanbul University Cerrahpaşa hospital, and Institute of Cardiology consists of employee health at the hospital and administrative staff. From August 30 to November 30, 2018, the research universe reached 2,000 people, of which 945 were returned.

\subsection{Research Method and Research Scales}

The survey method was used as a method of data collection within the scope of the research. The questionnaire used to collect the data is prepared in the form of a 7-point Likert scale. The data collected were subjected to frequency breakdown, validity, reliability, correlation, and regression analyses using statistical package programs. The questionnaire consists of four sections (as follows).The first section consists of brief information about scale measurement tools that indicate demographics and demographic information about institutions and employees.

In the second section, the organizational trust scale developed by Nyhan and Marlowe (1997) and adapted to Turkish by Demircan (2003) was used to determine the organizational trust perceptions of healthcare workers. Nyhan and Marlowe (1997) conducted reliability, explanatory factor analysis, and validity tests of the measurement instrument, which was used in the 2013 inner curveball thesis. This value is the organizational confidence scale of a high degree of reliability in statistics; it is a 12-point measurement tool consisting of two sub dimensions, i.e., trust in the manager and trust in the organization, and evaluates organizational trust as emotional, cognitive, and planned behavior. The sub dimension of trust in the manager consists of eight articles (i.e., articles 1-8). The sub dimension of trust in the organization consists of four articles (i.e., articles 9-12).

In the third section, the organizational citizenship behavior scale (Kabataş 2010; Erdoğan and Bedük, 2013), which has been used in previous research in Turkey developed by Podsakoff and others (1990) and translated (Turgut and Akbolat, 2017), was used in the paper work. The scale consists of five distinct dimensions: responsibility (altruism), kindness, feeling of belonging (conscientiousness), disciplined work (civic virtue), and sportsmanship. Altruism 1, 2,3,4 questions; civil virtue 13, 14, 15, 16 questions; conscientiousness 9, 10, 11, 12 questions; sportsmanship 17, 18, 19, 20 questions; civility 5, 6, 7, 8. There are four expressions to measure each dimension, with a total of 20 expressions on the scale.

The fourth part is the 20-question scale of job satisfaction (Churchill et al., 1974; Comer et al., 1989) developed by Schwepter (2001); the scale was translated into Turkish and proved its validity and reliability. The structure of the scale business will be evaluated with questions $2,13,17,18$; promotion questions $4,8,15$; fee questions 5, 9; manager questions 1,6 ; 12 , company policy questions 3, 7, 14; customers' questions 11, 19, 20; and colleagues' questions 10, 16.

\section{FINDINGS AND DISCUSSIONS}

This section contains the findings and evaluations of the thesis work. Descriptive statistics and factor analysis are presented in detail at Appendix 1 and 2(seen in Appendix). In order for the research to be scientific, the information must be accurate and must be proven by observations and experiments carried out each time. It is validity and reliability that make the research strong (Şencan, 2005). The method used to measure the reliability of a scale is Cronbach's Alpha ( $\alpha$ ) coefficient. Cronbach's Alpha ( $\alpha$ ) was revealed by Lee Cronbach in 1951 in reliability analysis (Yildiz and Uzunsakal, 2018). Cronbach Alpha examines the relationships between random samples in a variable and allows a coefficient indicating the correlations of that sample to be used in data set testing (Cronbach, 1951). Cronbach's Alpha $(\alpha)$ coefficient can be used in Likert type test items, even Cronbach's Alpha ( $\alpha$ ) coefficient can be used in all test items (Bademci,2006). Although there are several approaches in the literature, this value is 0.7 and greater. Several classifications exist for the interpretation of Cronbach's Alpha $(\alpha)$ coefficient. Illustrated in detail in the tables below (Kılıç, 2016). 
Table 1: Degree of Reliability of Scale Variables

\begin{tabular}{|l|c|c|}
\hline Variable Name Question & Number & Cronbach Alpha \\
\hline Organizational Trust & 12 & 0.947 \\
\hline Organizational Citizenship & 20 & 0.890 \\
\hline Job Satisfaction & 20 & 0.934 \\
\hline Total & 52 & 0.946 \\
\hline
\end{tabular}

It is observed that the lower dimensions of the questions that make up the research scale have a reliability value between 0,890 and 0,947 . In addition, a general reliability analysis with all questions of the scale was performed and the result was found to be 0.946. A higher reliability value than the arithmetic average of the lower dimensions that make up the scale can be considered as an indication of the alignment of the lower dimensions that make up the survey and that the scale is designed correctly. Two separate measurements were made to test the suitability of variables for factor analysis. Kaiser-Meyer-Olkin (KMO), which tests the adequacy of samples, is also Bartlett's Test of Sphericity test to measure sample proficiency and the level of correlation between variables. The KMO ratio is between 0 and 1 . The limit value for sample adequacy it is, 7. Table 2: as can be seen, the validity is excellent as the KMO value is, 932.

Table 2: Organizational Trust and Organizational Citizenship (Independent Variable) KMO and Bartlett's Test

\begin{tabular}{|l|c|c|}
\hline \multicolumn{3}{|c|}{ KMO and Bartlett's Test } \\
\hline Kaiser-Meyer-Olkin Measure of Sampling Adequacy. &, 932 \\
\hline \multirow{3}{*}{ Bartlett's Test of Sphericity } & Bartlett's Test of Sphericity & 20330.630 \\
\cline { 2 - 3 } & Df & 496 \\
\cline { 2 - 3 } & Sig & 000 \\
\hline
\end{tabular}

The Bartlett's Test of Sphericity is measured by whether the data meets the multivariate normality assumption (Katrancl and Temel,2018,). Significance (sig.) is stated as. The limit for this value is $<0.05$ (Hair et al., 2010). Table. the independent variables OT and OC are below the limit of 0.000 for all the variables studied. According to Bartlett's Test of Sphericity results, there is a significant correlation and correlation between all variables.

Table 3: Job Satisfaction Organizational Citizenship (Dependent Variable) KMO and Bartlett's Test

\begin{tabular}{|l|c|c|}
\hline \multicolumn{3}{|c|}{ KMO and Bartlett's Test } \\
\hline Kaiser-Meyer-Olkin Measure of Sampling Adequacy. &, 931 \\
\hline \multirow{3}{*}{ Bartlett's Test of Sphericity } & Bartlett's Test of Sphericity & 11811.651 \\
\cline { 2 - 3 } & Df & 190 \\
\cline { 2 - 3 } & Sig & 000 \\
\hline
\end{tabular}

As we can see in the Table 3, the dependent variable of the research is 0.000 and the validity is excellent since it is 0.931 for all variables. According to Bartlett's Test of Sphericity results, there is a significant correlation between all variables. The sample number of dependent and independent variables is perfect according to the number of variables and the variables are suitable for exploratory factor analysis.

Exploratory Factor Analysis -Exploratory factor analysis was performed to test the validity of the variables and scales that successfully passed the KMO and Bartlett's globalism tests. Each variable is made separately and shown in detail in the tables 9 (in the Appendix). When looking at the factor analysis Table, the organizational trust argument was examined in two subdimensions as trust in the organization and trust in the manager. Organizational citizenship is the argument if you assume the workload, and disciplined work is divided into three dimensions as a feeling of belonging. The dependent variable of job satisfaction is divided into two sub-dimensions as opposed to salary and promotion and institution. There is no conflict between the questions and the analyses were continued on the basis of this factor table. 19 questions were excluded from evaluation because they received no meaningful value. Correlation analysis was performed to examine the relationship between the variables. Specifies the direction and force of the relationship and is specified as the Pearson coefficient (Guriş and Astar, 2015). 
Table 4: Correlation Table

\begin{tabular}{|c|c|c|c|c|c|c|c|c|}
\hline & 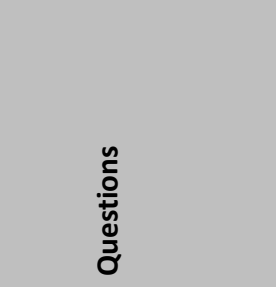 & 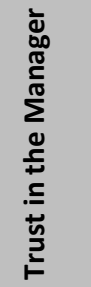 & 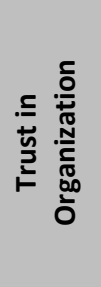 & 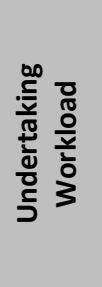 & 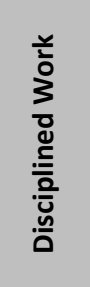 & 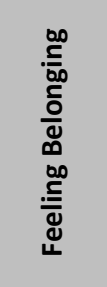 & 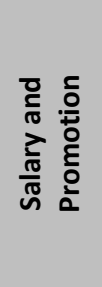 & 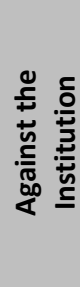 \\
\hline \multirow{3}{*}{$\begin{array}{l}\text { Trust in the } \\
\text { Manager }\end{array}$} & \multirow{3}{*}{$\begin{array}{c}\text { Pearson Correlation } \\
\text { Sig. (2-tailed) } \\
\text { N }\end{array}$} & 1 & & & & & & \\
\hline & & & & & & & & \\
\hline & & 945 & & & & & & \\
\hline \multirow{3}{*}{$\begin{array}{c}\text { Trust in } \\
\text { Organization }\end{array}$} & \multirow{3}{*}{$\begin{array}{c}\text { Pearson Correlation } \\
\text { Sig. (2-tailed) } \\
\text { N }\end{array}$} & $.687^{* *}$ & 1 & & & & & \\
\hline & & .000 & & & & & & \\
\hline & & 945 & 945 & & & & & \\
\hline \multirow{3}{*}{$\begin{array}{l}\text { Undertaking } \\
\text { Workload }\end{array}$} & \multirow{3}{*}{$\begin{array}{c}\text { Pearson Correlation } \\
\text { Sig. (2-tailed) } \\
\text { N }\end{array}$} & $.305^{* *}$ & $.244^{* *}$ & 1 & & & & \\
\hline & & .000 & .000 & & & & & \\
\hline & & 945 & 945 & 945 & & & & \\
\hline \multirow{3}{*}{$\begin{array}{l}\text { Disciplined } \\
\quad \text { Work }\end{array}$} & \multirow{3}{*}{$\begin{array}{c}\text { Pearson Correlation } \\
\text { Sig. (2-tailed) } \\
\text { N }\end{array}$} & $.269^{* *}$ & $.234^{* *}$ & $.666^{* *}$ & 1 & & & \\
\hline & & .000 & .000 & .000 & & & & \\
\hline & & 945 & 945 & 945 & 945 & & & \\
\hline \multirow{3}{*}{$\begin{array}{l}\text { Feeling } \\
\text { Belonging }\end{array}$} & \multirow{3}{*}{$\begin{array}{c}\text { Pearson Correlation } \\
\text { Sig. (2-tailed) } \\
\text { N }\end{array}$} & .027 & -.008 & $.120^{* *}$ & $.188^{* *}$ & 1 & & \\
\hline & & .411 & .807 & .000 & .000 & & & \\
\hline & & 945 & 945 & 945 & 945 & 945 & & \\
\hline \multirow{3}{*}{$\begin{array}{l}\text { Salary and } \\
\text { Promotion }\end{array}$} & \multirow{3}{*}{$\begin{array}{c}\text { Pearson Correlation } \\
\text { Sig. (2-tailed) } \\
\text { N }\end{array}$} & $.357^{* *}$ & $.486^{* *}$ & $.068^{*}$ & $.138^{* *}$ & $-.196^{* *}$ & 1 & \\
\hline & & .000 & .000 & .037 & .000 & .000 & & .000 \\
\hline & & 945 & 945 & 945 & 945 & 945 & 945 & 945 \\
\hline \multirow{3}{*}{$\begin{array}{l}\text { Against the } \\
\text { Institution }\end{array}$} & \multirow{3}{*}{$\begin{array}{c}\text { Pearson Correlation } \\
\text { Sig. (2-tailed) } \\
\text { N }\end{array}$} & $.572^{* *}$ & $.604^{* *}$ & $.364^{* *}$ & $.429^{* *}$ & .003 & $.705^{* *}$ & 1 \\
\hline & & .000 & .000 & .000 & .000 & .917 & .000 & \\
\hline & & 945 & 945 & 945 & 945 & 945 & 945 & 945 \\
\hline
\end{tabular}

When looking at the correlation table, the first striking detail is the relationship of the sub dimensions of it, which are the dependent variables of the research, to the sub dimensions of other independent variables. The sub-dimensions of trust in the manager, trust in the staff, and workload are all moderately related to both dimensions of dependent variables. Pearson correlation coefficient 0.357 between trust in the manager and (salary and promotion) of the job satisfaction sub-dimensions of the argument with the organization trust sub- dimension. Regression analysis was used to examine the relationships between variables (Şenel and Alatlı,2014). Which is used to estimate random variable behavior as a model and specifies the magnitude of the relationship between variables. The $T$ test for the individual statistical significance of the parameters and the $F$ test for the overall significance of the model are looked at (Küçüksille, 2010). The regression-dependent variable is shown as wage and salary versus institution in the form of 2 models.

Table 5: Regression Table (Salary and Promotion)

\begin{tabular}{|c|c|c|c|c|c|c|}
\hline \multicolumn{2}{|c|}{ Model } & Sum of Square & Df & Mean Square & F & \multicolumn{1}{c|}{ Sig } \\
\hline \multirow{4}{*}{1} & Regression & 552.753 & 5 & 110.551 & 75.631 & $.000^{\mathrm{b}}$ \\
\cline { 2 - 7 } & Residual & 1372.539 & 939 & 1.462 & & \\
\cline { 2 - 7 } & Total & 1925.292 & 944 & & Std. Error of the Estimate \\
\cline { 2 - 7 } & & R Square & Adjusted R Square & 1.20901 \\
\hline
\end{tabular}




\begin{tabular}{|c|c|c|c|c|}
\hline Variables & Std. Error & $\begin{array}{c}\text { Beta(Standar } \\
\text { dize) }\end{array}$ & T & Sig. \\
\hline Constant & .250 & --- & 8.371 & .000 \\
\hline Trust in the Manager & .038 & .060 & 1.543 & .123 \\
\hline Trust in Organization & .036 & .441 & 11.597 & .000 \\
\hline Undertaking workload & .043 & -129 & -3.449 & .001 \\
\hline Disciplined Work & .051 & .144 & 3.829 & .000 \\
\hline Feeling Belonging & .027 & -.205 & -7.305 & .000 \\
\hline
\end{tabular}

a. ( Dependent Variable): Job satisfaction (Salary and Promotion )

b. (Independent Variable): Trust in the Manager, Trust in Organization, Undertaking workload, Disciplined Work, Feeling Belonging

Organizational citizenship behavior and organizational citizenship behavior were associated with the workload (both salary and promotion) at a moderate level (against the organization). It has no relation with salary and promotion and feeling of belonging to the institution or even potentially negatively charged, the dependent variable (salary and promotion) has no interaction with the independent variable of trust in the manager, which is the lower dimension of organizational trust. It was found that the lower dimension of job satisfaction (salary and promotion) dependent variable, the lower dimensions of organizational citizenship behavior negatively affect the workload and sense of belonging independent variable. Organizational trust was found to be directly related to job satisfaction ( salary and promotion), the independent variable of disciplined work, which is the lower dimension of organizational trust, the lower dimension of organization, and the lower dimension of organizational citizenship. The determination coefficient of this model is 0.287 . In other words, $28,7 \%$ of the changes in the dependent variable, due to variations in these three sub-dimensions.

Tablo 6: Regression Table (Against the Institution)

\begin{tabular}{|c|c|c|c|c|c|c|}
\hline \multicolumn{2}{|c|}{ Model } & \multirow{2}{*}{$\begin{array}{c}\text { Sum of Square } \\
684.462 \\
\end{array}$} & \multirow{2}{*}{$\begin{array}{l}\text { Df } \\
5 \\
\end{array}$} & \multirow{2}{*}{$\begin{array}{c}\text { Mean Square } \\
136.892\end{array}$} & \multirow{2}{*}{$\begin{array}{c}\mathbf{F} \\
176.804 \\
\end{array}$} & \multirow{2}{*}{$\begin{array}{c}\text { Sig } \\
.000^{\mathrm{b}} \\
\end{array}$} \\
\hline \multirow{12}{*}{2} & Regression & & & & & \\
\hline & Residual & 727.032 & 939 & .774 & & \\
\hline & Total & 1411.494 & 944 & & & \\
\hline & & $\mathbf{R}$ & R Square & Adjusted R Square & \multicolumn{2}{|c|}{ Std. Error of the Estimate } \\
\hline & & $.696^{a}$ & .485 & .482 & \multicolumn{2}{|c|}{.87992} \\
\hline & Variables & Std. Error & Beta(Standardize) & $\mathbf{T}$ & \multicolumn{2}{|c|}{ Sig. } \\
\hline & Constant & .182 & & 2.826 & \multicolumn{2}{|c|}{.005} \\
\hline & Trust in the Manager & .028 & .237 & 7.213 & \multicolumn{2}{|c|}{.000} \\
\hline & Trust in Organization & .026 & .370 & 11.449 & \multicolumn{2}{|c|}{.000} \\
\hline & Undertaking workload & .031 & .028 & .881 & \multicolumn{2}{|c|}{.379} \\
\hline & Disciplined Work & .037 & .270 & 8.448 & \multicolumn{2}{|c|}{.000} \\
\hline & Feeling Belonging & 0.20 & -.054 & -2.266 & \multicolumn{2}{|c|}{0.024} \\
\hline
\end{tabular}

It was revealed that the dependent variable, which is the sub-dimension of job satisfaction (against the institution), is directly positively related to trust in the manager, trust in the organization and the independent variable of disciplined work. The determination coefficient of this model is 0.485 . In other words, $48,5 \%$ of the changes in the dependent variable, due to variations in these three sub-dimensions. In addition to the findings, the agent variable relationship was examined. Variables are models that define the relationship between dependent and independent variables by partial or complete means. It examines not the direct relationship between dependent and independent, but the relationship of the independent variable with the intermediary variable and the dependent variable in the intermediary variable (Yilmaz and Ilhan Dalbudak, 2018). if the relationship between the independent variable and the dependent variable is overshadowed by another variable that enters the model, then there is an intermediate variable ( Altindag, 2011). The intermediary variable cannot be associated with foresight and clearly shows the interaction of the variable (Baron and Kenny,1986). 
Figure 1: Variable Relations Deciduous

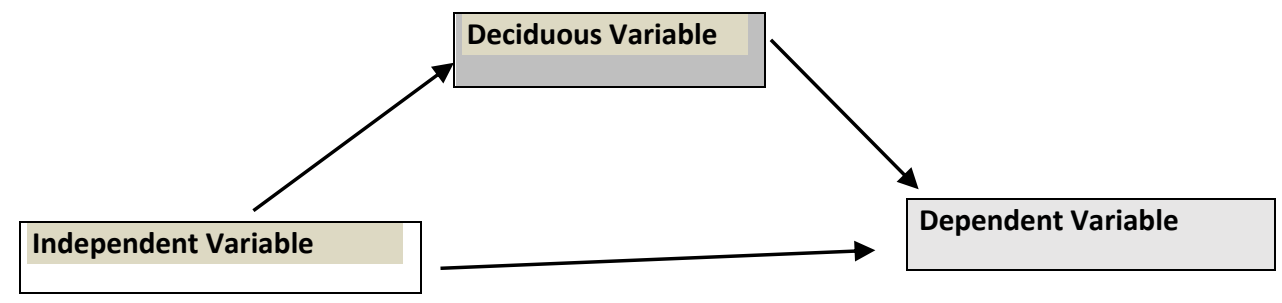

Form 2: Altındağ, E.(2011) Aile Şirketlerinde Stratejik Yönelim Düzeylerinin Tespiti ve Firma Performansı Üzerinde Etkisi, Yayınlamış Doktora Tezi, Gebze İleri Teknoloji Enstitüsü, Gebze,

Table 7: Moderator Variable Relation

\begin{tabular}{|l|c|c|}
\hline \multirow{2}{*}{ Agent Variable Relation } & Step 1 & Step 2 (All Model) \\
\hline \multirow{2}{*}{ Undertaking Workload -> Job Satisfaction } & Original Example (B) & Original Example (B) \\
\hline Disciplined Work -> Job Satisfaction &,- 046 & ----- \\
\hline Feeling Belonging -> Job Satisfaction &, 212 & ------ \\
\hline Undertaking Workload -> Organizational Trust -> Job Satisfaction &,- 230 &,- 129 \\
\hline Disciplined Work -> Organizational Trust -> Job Satisfaction & ---- &, 144 \\
\hline Feeling Belonging -> Organizational Trust -> Job Satisfaction & ------ &,- 205 \\
\hline \multirow{2}{*}{ R Square Value } & ------- & Organizational Citizenship : 0,071 \\
\hline
\end{tabular}

Organizational citizenship and job satisfaction in the relationship between organizational trust has an instrumental effect In addition to the results of the intermediate variables in the study, no significant intermediary effect was determined when a decoupling was performed over the Beta value.

Table 8: Research Hypotheses and Results

\begin{tabular}{|c|c|c|}
\hline NO & HYPOTHESIS & RESULT \\
\hline H1 & $\begin{array}{l}\text { Organizational trust has a positive impact on job } \\
\text { satisfaction }\end{array}$ & Partially supported \\
\hline H1a & Trust in a manager has a positive effect on job satisfaction & $\begin{array}{l}\text { Salary and promotion don't affect size. According to } \\
\text { the institution, the direct and positive effect of job } \\
\text { satisfaction }\end{array}$ \\
\hline H1b & $\begin{array}{l}\text { Trust in an organization has a positive effect on job } \\
\text { satisfaction. }\end{array}$ & $\begin{array}{l}\text { Direct and positive effect with both dimensions of job } \\
\text { satisfaction }\end{array}$ \\
\hline $\mathrm{H2}$ & $\begin{array}{l}\text { Organizational citizenship has a positive effect on job } \\
\text { satisfaction. }\end{array}$ & Partially supported \\
\hline $\mathrm{H} 2 \mathrm{a}$ & $\begin{array}{l}\text { Undertaking workload has a positive effect on job } \\
\text { satisfaction. }\end{array}$ & $\begin{array}{l}\text { Negative impact on salary and promotion and no } \\
\text { impact on the institution }\end{array}$ \\
\hline $\mathrm{H} 2 \mathrm{~b}$ & Disciplined work has a positive effect on job satisfaction & Direct and positive effect with both dimensions of it \\
\hline $\mathrm{H} 2 \mathrm{c}$ & $\begin{array}{l}\text { Feeling of belonging has a positive effect on job } \\
\text { satisfaction }\end{array}$ & $\begin{array}{l}\text { With salary and promotion, it has no impact in a } \\
\text { potentially negative way and against the institution }\end{array}$ \\
\hline
\end{tabular}




\begin{tabular}{|l|l|l|}
\hline H3 & $\begin{array}{l}\text { Organizational citizenship and job satisfaction in the } \\
\text { relationship between organizational trust has an } \\
\text { instrumental effect }\end{array}$ & Not supported \\
\hline
\end{tabular}

\section{CONCLUSION}

As a result of the research, we determine if health care businesses achieve superiority by differentiating themselves from other businesses in the intense competitive environment created by globalization, thanks to the effects of organizational trust and organizational citizenship on job satisfaction. The first hypothesis is that organizational trust has a positive effect on job satisfaction there is a moderate relationship among job satisfaction (salary and promotion satisfaction) and the dependent variable (satisfaction against the institution) and the independent variables of trust in a manager and organization, which are the lower dimensions of organizational trust. Trust in a manager typically does not affect salary and promotion satisfaction. However, satisfaction toward the institution was also seen as a direct positive relationship to the manager and the organization. The most important reason for this is related to the structure of health institutions. Because the health sector uses high technology and is the most important of the service sectors, health management requires high costs, which are typically difficult to manage. The organizational structures of university hospitals differ from other health institutions due to the different missions they are expected to perform. Since these hospitals provide health services and also carry on training and research activities, arrangements are made in their organizational structures. Generally, university hospitals are managed by a matrix structure. This creates a twoway matrix. In this management style, specialization, standardization, flexibility, and complexity due to hierarchy, high costs are seen.

The reason why salary and promotion, which are at the lower dimension of job satisfaction in research, are not affected by trust in a manager is that the university hospitals in our research are government agencies. In these institutions, due to the standard of salaries and additional payments, the performance fee is equal and fair distribution of high-performing employees with wages between them will be no different in terms of the most underperforming employee, and the influence of the reward system of low job satisfaction and organizational trust. University hospitals face numerous difficulties in the promotion system, i.e., promotions are not distributed in a fair manner and are left entirely at the initiative of the manager; further, promotions education, merit, knowledge, experience, and talent are not given importance to be done arbitrarily as an example can be given. Although the employee does not trust the manager, the relationship between trust in the organization and job satisfaction is seen as being positive. There is no relationship between trust in the manager and salary and promotion, which is at the lower dimension of job satisfaction, i.e., the salary and promotion dependent variable is not affected by trust in the manager. This is due to the fact that it is a public university hospital, and the salary and wages are determined by law, whereby the administrator is no longer effective. The general job satisfaction variable (against the institution) and trust in the organization and the manager are directly positive. The reason for this is that, when employees trust the institution and the manager, they perform more, strive to please the manager, and become easier to create job satisfaction, except for salaries and wages, the employee exhibits job satisfaction and trusts the manager and the organization.

The second hypothesis of the study is that organizational citizenship behavior has a positive effect on job satisfaction. In this study, the organizational citizenship dimension was reduced from five to three sub dimensions: workload (altruism); feeling of belonging (conscientiousness); disciplined work (civic virtue). There is a moderate relationship among the workload-taking argument and the job satisfaction (salary and promotion) and (institution-versus-institution) dependent variables. Colleagues and employees voluntarily and willingly help beginners' failover workload. Due to the fact that taking on a workload is a behavior that exhibits not waiting for a response, it has moderately affected both aspects of job satisfaction. The success of organizations increases thanks to employees who exhibit this behave, and changes and developments are achieved. When the wages, awards, and promotions among the organization's employees are offered fairly and equally, when the corporate culture is developed, when the employees are allowed to be together in a social environment, the employees' job satisfaction will increase as the workload will improve. There was no relationship between feeling belonging to the institution and job satisfaction in either dimension. Even a potentially negative directional relationship has been identified. This shows that, although health workers do not have job satisfaction, they perform many jobs outside of their official duties. Regardless of job satisfaction, the health worker will typically participate actively and voluntarily in organizational activities and organizational life, thus keeping the best interests of the organization at the highest level. There is a negative correlation between taking on a workload and the feeling of belonging and salary and promotion. This shows that employees are happy to do jobs other than routine jobs, even if they are not given any pay or promotion. Health workers are always performing at the highest level, despite working under strenuous and difficult working conditions. Although they encounter much impossibility in the work environment, their motivation never drops, and they do their 
best to restore the health of the patients. Further, they do it willingly, without expecting any recompense for what they have done. A direct positive correlation was found in both aspects of job satisfaction with the disciplined study. Thus, employees exhibit behaviors such as coming to work on time, using the work time effectively, and wholeheartedly obeying the rules set out in the work environment. Job satisfaction is a feeling experienced as a result of realizing that what you get as a result of work and work allows you to meet or disagree with your material, moral, and personal value judgments. The more conscientious behaviors the employee exhibits, the greater the job satisfaction. When the employee exhibits conscientious behavior, job satisfaction will increase as the way success is felt in terms of quality and quantity. Behavior, organizational citizenship behavior, and strings, despite the success of the organization, are necessary for proper behavior. Organizations should value employees if they want the employee to be successful and happy at work and in social life.

\section{REFERENCES}

Abanech, K. I and Hackett, D. R. (2019). The direct and indirect impacts of job characteristicsistep faculty organizational citizenship behavior in the United Arab Emirates (UAE).High Educ (2019) 77:19-36 https://doi.org/10.1007/s10734-018-0252-3.

Akbulut, S. (2017). Yabancılaşma olgusunun örgütsel güven ve örgütsel vatandaşlık davranışına etkisi üzerine bir araştırma: Adıyaman Üniversitesi örneği, yayınlanmış yüksek lisans tezi, Adıyaman Üniversitesi Sosyal Bilimler Enstitüsü, Adıyaman.

Akıncı Tanyıldı, H.B and Serin, H. (2020). The relationship between organizational image and organizational citizenship perception of academicians, International Journal of Education \& Literacy Studies IJELS, 8(1): 14-23. ISSN: 2202-9478

Alev, S. (2019). Kolaylaştıııı okul yapısı ve örgütsel vatandaşlık davranışları arasındaki ilişkinin incelenmesi, Opus-Uluslararası Toplum Araştırmaları Dergisi, 10(17): 420-443, DOI: 10. 26466/OPUS.51800

Altındağ, E. (2011). Aile şirketlerinde stratejik yönelim düzeylerinin tespiti ve firma performansı üzerinde etkisi, yayınlanmış doktora tezi, Gebze Yüksek Teknoloji Enstitüsü, Gebze.

Anvari, R., Chikaji, A and Abu Mansor, N. N.(2015). Relationship between organizational citizenship behavior and job performance among engineers, Journal of Teknoloji ,77(13):159-164,2015, ISSN 0127-9696, EISSN : 21803722

Artar,M., Adıgüzel,Z and Erdil, O (2019). Örgütlerde yöneticiye duyulan güvenin, psikolojik sözleşme ihlali, örgütsel dışlanma ve iş tatmini arasındaki ilişkilerin incelenmesi, İ̧̧letme Araştırmaları Dergisi, Journal of Business Research-Turk,11(3):14171432https://doi.org/10.20491/isarder.2019.680.

Avram, E., Lonescu, D and Mincu, L. (2015).Perceived safety climate and organizational trust: the mediator role of job satisfaction, Procedia Social And Behavioral Sciences, 187: 13 Mayıs,2015 , 679 - 684 https://doi.org/10.1016/j.sbspro.2015.03.126 ISSN: 1877-0428

Aydan, S and Kaya, S.( 2018). Hemşirelerin etik iklim algılarının örgütsel güven düzeyleri üzerindeki etkisi, Hacettepe Sağlık İdaresi Dergisi, 21(2): 199-216. https://www.researchgate.net/profile/Seda_Aydan/publication/326059648

Aydın, S.( 2017). Örgütsel güven iş tatmini ilişkisi: İstanbul'daki 4-5 yıldızlı otellerde çalışanlar üzerinde bir araştırma, yayınlanmış yüksek lisans tezi, Nişantaşı Üniversitesi Sosyal Bilimler Enstitüsü, İstanbul

Bademci, V. (2006). Tartışmayı sonlandırmak: Cronbach'ın alfa katsayısı, iki değerli $(0,1]$ ölçümlenmiş maddeler ile kullanılabilir, Kazım Karabekir Eğitim Fakültesi Dergisi .13,438-446. (http://e-dergi.atauni.edu.tr/index.php/kkefd/article/viewFile/4116/3940).

Baron, M. R and Kenny, D. A(1986).The Moderator-Mediator Variable Distinction in Social Psychological Research: Conceptual, Strategic, and Statistical Considerations, Journal of Penality and Social Psychology Copyright 1986 by the American Psychological Association,51(6): 1173-1182, file:///C:/Users/Ngl/Downloads/BaronKenny 86.pdf

Bil, E. (2018). Ortaöğretim okullarının öğrenen örgüt, örgütsel güven ve iş doyumu düzeyleri arasındaki ilişki, yayınlanmış doktora tezi, Ankara Üniversitesi Eğitim Bilimleri Enstitüsü, Ankara, 2018.

Biswas, N and Masumder, Z. (2017). Exploring organizational citizenship behavior as an outcome of job satisfaction: a critical review, The Lup Journal Of Organizational Behavior, 16, 2,7-16. https://eds.a.ebscohost.com/eds/pdfviewer/pdfviewer?vid=0\&sid=6ed97d16-3f91-4dd1-9171b333a5474b2b\%40sessionmgr4008.

Bromiley, L.L and Cummins, P., Ed,( Kramer. R. M., Tyler, T. R ).(1996) The organizational trust inventory (oti), development and validation, trust in organizations frontiers of theory and research, Sage Publications, London, New Delphi https://books.google.com.tr/books?hl=tr\&lr=\&id=A_8LbcsgrNMC\&oi=fnd\&pg=PA302\&dq.

Büyükyılmaz, O. (2018). Relationship between person- organization fit and organizational citizenship behavior : the mediating role of job satisfaction international journal of management and administration ,2( 4):135-146, DOI Number: 10.29064/ijma.464856. 
Büyükyılmaz, O and Fidan, Y. (2017). Algılanan örgütsel desteğin örgütsel vatandaşlık davranışı üzerindeki etkisinde örgütsel güvenin aracılık rolü, Business \& Management Studies: An International Journal, 5(3), 500-524 ,doi:http://dx.doi.org/10.15295/bmij.v5i3.143.

Büyükyılmaz, O and Yeğin, T. (2017). Anka çalışanları tarafından algılanan kişi örgüt-uyumu ve iş tatmininin örgütsel vatandaşlık davranışı üzerindeki etkisi, dergipark sosyal bilimler metinleri, s: 75-87.

Cankül D., Kılıç, İ and Doğantekin, A. (2018) Restorant çalışanlarının algılamış oldukları örgütsel güven düzeylerinin örgütsel vatandaşlık ve iş performansına etkisi: Eskişehir örneği, (Journal of Tourism And Gastronomy Studies, 6(1): 372-389, DOI: 10.21325/jotags.2018.193.

Cindiloğlu Demirer, M. (2019). Kişi örgüt uyumunun iş performansına olan etkisi: mutluluğun aracılık rolü, Iktisadi ve Idari Bilimler Dergisi, 33(1): 283-301, https://www.researchgate.net/publication/330938644.

Churchill, G., Ford, N. M and Walker, O. C. (1974). Measuring the job satisfaction of industrial salesmen, Journal of Marketing Research, 1(3): 254-260, Stable URL: http://www.jstor.com/stable/3151140.

Comer, J.M., Machleit, K.A and Lagece, R.A.( 1989).Psychometric assessment of a reduced version of indsales, Journal of Business Research, 18, 4: 291-203, https://EconPapers.repec.org/RePEc:eee:jbrese:v:18:y:1989:i:4:p:291-302.

Cronbach, L. J. (1951). Coefficient Alpha and the Internal Structure of Tests, Psychometrika, 16, 3, https://link.springer.com/content/pdf/10.1007/BF02310555.pdf.

Çelebi, N and Tatik, R. Ş. (2019). Prediction of level of job satisfaction of teachers on perception of organizational trust of teachers: study of regression analysis. Kastamonu Education Journal, 27(5): 2103-2114 https://doi.org/10.24106/kefdergi.3323.

Çiçek, H and Şahin Macit., N. (2016).Konaklama işletmelerinde çalışanların örgütsel güveni íle iş tatmini arasındaki ilişkinin incelenmesi, $\begin{array}{lllll}\text { MehmetAkif Ersoy } & \text { Üniversitesi } & \text { Sosyal } & \text { Bilimler } & \text { Enstitüsü }\end{array}$ https://www.researchgate.net/profile/Hueseyin_Cicek2/publication/300086144.

Dede, E. (2017). İş güvencesizliği algısının ve örgütsel güven düzeyinin örgütsel vatandaşlık davranışı üzerine etkileri: devlet ortaokulu ve özel ortaokul öğretmenleri üzerine bir araştırma, (doktora tezi), İstanbul Ticaret Üniversitesi Sosyal Bilimler Enstitüsü, İstanbul.

Demiralp, M. (2018). Personel güçlendirmenin örgütsel güven ve iş tatmini ile illişkisi: görgül bir araştırma, yayınlanmış yüksek lisans tezi, Türk Hava Kurumu ÜniVersiTesi Sosyal Bilimler EnstiTüsü , Ankara.

Demircan, N, A. (2003). Örgütsel güvenin bir ara değişken olarak örgütsel bağlılık üzerindeki etkisi: Eğitim sektöründe bir uygulama, yanınlanmış doktora tezi Gebze Yüksek Teknoloji Enstitüsü,Sosyal bilimler Enstitüsü. Gebze.

Envergil, D. (2018). Sağlık çalışanlarının psikolojik sözleşme algılarının örgütsel güven, örgütsel özdeşleşme örgütsel vatandaşlık davranışı üzerindeki etkisi, Hacettepe Üniversitesi Sosyal Bilimler Enstitüsü, yayınlanmış yüksek lisans tezi, Ankara, 2018.

Erdoğan, P and Bedük, A. (2013). Örgütsel sinizm ile örgütsel vatandaşlık davranışı arasındaki ilişki: sağlık sektöründe bir araştırma, Sosyo Teknik Sosyal Ve Teknik Araştırmalar Dergisi, 3 ( 6 ): 17-36.

Erdoğan, P and İraz, R. (2019). Örgütsel vatandaşlık, örgütsel sinizm ve tükenmişliğe pozitif psikolojik sermaye etkisi, eğitim yayınevi, yayıncı sertifika no: 14824, 1.baskı, Konya, 2019.

Erdoğdu, F. B and Sökmen, A. (2019). Örgütsel bağlıık ile iş tatmini ve işten ayrılma niyeti ilişkisinde örgütsel vatandaşlık davranışının aracılık rolü, Journal Of Tourism And Gastronomy Studies, 7 (1): 244-264 https://www.jotags.org/2019/vol7_issue1_article13.pdf.

Ersan, H. (2018). Sağlık kurumlarında örgütsel güven ve örgütsel vatandaşılık davranışı ilişkisi ve bir araştırma, yayınlanmış yüksek lisans tezi, Pamukkale Üniversitesi Sosyal Bilimler Enstitüsü, Denizli.

Fard, P. G., Karimi. F. (2015). The relationship between organizational trust and, organizational silence with job satisfaction and organizational commitment of the employees of university , International Education, Studies, 8(11): 219-227.

Filiz, M and Bardakçı, S. (2020). Sağlık çalışanlarının örgütsel iklim algıları ve örgütsel güven düzeyleri arasındaki ilişkinin incelenmesi: Artvin ili örneği, elektronik sosyal bilimler dergisi 19(73): 436-449, ISSN: 1304-0278.

Gider, Ö., Akdere, M and Top, M. (2019). Organizational trust, employee commitment and job satisfaction in Turkish hospitals: implications for public policy and health, EMHJ. 25 (9): 622-629.

Gopinath, R and Shibu., N. S. (2016)., Few hrd factors influencing job satisfaction - a study with reference to BSNL three different ssas, International Journal Of Management,7( 2): 379-384.

Gupta and Singla, A.(2016). Organizational change and job satisfaction: An analyses of mediating effect of organizational trust, Indian Journal Of Commerce \& Management Studies, 7 (3): 7-13.

Güriş, S and Astar, M. (2015). Bilimsel araştırmalarda SPSS ile istatistik, DR Yayınları, yayın no: 444, genişletilmiş 2.basım, i̇stanbul, 2015. 
Hair J, Black W, Babin BJ, et al. (2010). Multivariate Data Analysis, New Jersey: Pearson Higher Education.

Harbalıoğlu, M.(2014). Örgütsel sessizlik ve örgütsel vatandaşlık davranışı arasındaki ilişki: konaklama işletmeleri üzerine bir araştırma, yayınlanmış yüksek lisans tezi, Gazi Üniversitesi Eğitim Bilimleri Enstitüsü, Ankara.

Hosmer, L. T. (1995). Trust: The connecting link between organizational theory and philosophical ethics, Academy of Management Review, 20 ( 2),379-403.

İnan, İ. E and Çelik, E. (2018). Algılanan örgütsel güven ve iş tatmini: Kastamonu ili özel ve kamu bankalarında bir uygulama, Al - Farabi Uluslararası Sosyal Bilimler Dergisi, 2 (3):23-52. ISSN- 2564- 7946.

İşcan, Ö. M and Sayın, U. (2010). Örgütsel adalet iş tatmini ve örgütsel güven arasındaki ilişki, Atatürk Üniversitesi Iktisadi ve idari Bilimler Dergisi, 24 4): 195-216, t: https://www.researchgate.net/publication/290344928.

Jafarova, F and Sağlam, N.(2018). Çalışanların iş tatmini, örgütsel bağlılık ve işten ayrılma niyetlerinin karşılaştırmalı analizi, Istanbul Aydın Üniversitesi Dergisi, 10(3): 57-82.

Kabataş, A. (2010). Örgütsel sinizm ile örgütsel vatandaşlık davranışı arasındaki ilişkilerin incelenmesi ve bir araştırma, yüksek lisans tezi, Kocaeli Üniversitesi, Sosyal Bilimler Enstitüsü, Kocaeli,

Karaman, A and Aylan, S.( 2012). Örgütsel vatandaşlık, Sütçü Imam Üniversitesi Iktisadi Ve Idari Bilimler Dergisi, agris. fao. org 35-48,

Katrancı., M., Temel, S. ( 2018). İlkokul Öğrencilerine yönelik yazma kaygısı ölçeği: geçerlik ve güvenirlik çalışması, Journal of Social And Humanities Sciences Research (JSHSR),5 (24): 1544-1555.

Khalifa, S. M. A and Awad, N. H. A.(2018).The relationship between organizational justice and citizenship behavior as perceived by medical surgical care nurses, I Journal Of Nursing And Health Science, 7(4) : 31-37.

Khıbanı, M. M., Abdızadeh, M and Barota, M. B.(2014). İmplementation of organizational citizenship behavior model in the Iranian healthcare industry, Wulfenıa, Journal Klagenfurt Austrı85-106,

https://www.scirp.org/(S(351jmbntvnsjt1aadkposzje))/reference/ReferencesPapers.aspx?ReferencelD=2569307

Kılıç, S., ( 2016).Cronbach'ın alfa güvenirlik katsayısı, Journal Of Mood Disorders, 6 (1):47-48, 2016 - www.jmood.org,

Kim J, H., Tavitiyaman, P and Kim, W,G. (2009).The effect of management commitment to service on employee service behaviors: the mediating role of job satisfaction, Journal Of Hospitality \& Tourism Research,33(3):369-390.

Küçüksille, E. (2010).( Editör, SPSS Uygulamalı Çok Değişkenli İstatistik Teknikleri, Çoklu Doğrusal Regresyon Modeli, Asil Yayın Dağıtım, 5.Baskı, Ankara.

Li, M., Dıaz,P. A. P., Mao. Y and Petrıdes, K.V.( 2018). A multilevel model of teachers' job performance: understanding the effects of trait emotional intelligence, job satisfaction, and organizational trust, Frontiers Psychology, 9, Article :2420, www.frontiers.org., 2018.

Mahmoudı, S., Hassanı, M and Aghlmand, S.( 2017). The relationship between organizational justice and organizational citizenship behavior among nurses (examining the mediating role of organizational commitment, organizational trust, and job satisfaction, Patient Saf Qual Improv, 5(2):513- 520 article_8544_0efdec6fe4ab22d3629989329530e11e.

Memduhoğlu, H. B and Zengin, M.(2017). Örgütsel güven, H.B. Memduhoğlu., \& Yılmaz, K .(Ed.).Yönetimde yeni yaklaşımlar içinde, Ankara: vadi grup ciltevi, 350-365, Ankara.

Mishra, J and Morrissey, M. A. (1990). Trust in employee / employer relationships: a survey of west michigan managers, Public Personnel Management, 19, (4): 443-485, https://doi.org/10.1177/009102609001900408

Nam, S.( 2018). Psikolojik sözleşme ve iş tatmini ilişkisi üzerine bir araştırma, International European Journal of Managerial Research Dergisi, (EUJMR),2,(3): 43-60, ISSN: 2602-3970,2018.

Nasra, M, A., Heilbrunn, S. (2016).transformational leadership and organizational citizenship behavior in the arab educational system in ısrael: the impact of trust and job satisfaction, Educational Management Administration and Leadership, 44(3): 380-396, DOI: 10.1177/1741143214549975.

Nyhan, R. C and Marlowe, H. A. 1997, "Development and psychometric properties of the organizational trust inventory”, Evaluation Review, vol. 21 , no. 5, pp. 614-635.

Organ,D.W.( 1997). Organizational Citizenship Behavior, It is Construct Clean -Up Time , Human Performance, $10(2$ ): 85,97.

Öktem, Ş., Kızıltan, B and Öztoprak, M. (2016). Örgütsel güven ile örgüt ikliminin örgütsel özdeşleşme, iş tatmini ve işten ayrılma niyeti üzerine etkileri: otel işletmelerinde bir uygulama, İşletme Araştırmaları Dergisi, 8 (4):162-186. DOI: 10.20491/isarder.2016.212 . 
Önder, M and Yavuz, E. (2019). İ̧ görenlerin örgütsel güven algılarının belirlenmesi: üniversite çalışanları üzerinde bir inceleme, Afyon Kocatepe Üniversitesi Sosyal Bilimler Dergisi, 21(1): 307-329, DOI: 10.32709/akusosbil.508738.

Örücü, E and Kaçan, A.(2019). İş tatminin örgütsel vatandaşlık davranışı üzerine etkisi: eczane sektörü üzerine bir araştırma, Sosyal Bilimler AraşTırmaları Dergisi BANÜSAD, 2 (1):167-189,.

Özafşarlıoğlu Sakallı, S. (2015). Örgütsel adalet ile örgütsel güven ilişkisinde kişilik özelliklerinin düzenleyici rolü ve bir Alan araştırması. Yayınlanmamış doktora tezi, Balıkesir Üniversitesi Sosyal Bilimler Enstitüsü Işletme Anabilim Dalı, Balıkesir.

Pars Şener, M. (2017). Okul Yöneticilerinin Kullandıkları Güç Kaynakları ile Öğretmenlerin Örgütsel Güven Düzeyleri, Yüksek Lisans Tezi, On Dokuz Mayıs Üniversitesi Eğitim Bilimleri Fakültesi, Samsun.

Pouranini, Z and Fayyazi, M. (2015). The relationship between positive organizational behavior with job satisfaction, organizational citizenship behavior, and employee engagement, International Business Research, 8(9): 57-66.

Prasetio, A., Yunıarsiht, T and Ahman, E. (2017). Job satisfaction, organizational commitment, and organizational citizenship behavior in stateowned banking, Universal Journal of Management, 5(1): 32-38, DOI: 10.13189/ujm.2017.050104.

Sawitri, D., Suswati, E and Huda, K. (2016). The impact of job satisfaction, organization commitment, organizational citizenship behavior (ocb) on employees'performance, The International Journal of Organizational Innovation, 9( 2) :24-45.

Schwepker , J. C. H.( 2001). Ethical climate's relationship to job satisfaction,organizational commitment, and turnover intention in the salesforce, Journal of Business Research, 54: 39- 52.

Singh, Kh. D and Onahing , B. D. (2019). Entrepreneurial intention, job satisfaction and organisation commitment - construct of a research model through literature review, Journal Of Global Entrepreneurship Research, 9(6 ): 1-18, https://doi.org/10.1186/s40497-018-0134-2.

Sing, U and Srivastava, K.B. L. (2016). Organizational trust and organizational citizenship behaviour, Global Business Review, 17 (3) : 594-609, DOI: $10.1177 / 0972150916630804$.

Sökmen, A. (2019). Etik liderlik, örgütsel güven, iş tatmini ve işten ayrılma niyeti ilişkisi: bir hastane işletmesinde araştırma, Üçüncü Sektör Sosyal Ekonomi Dergisi,54( 2) : 917-934, doi: 10.15659/3.sektor-sosyal-ekonomi.19.05.1123.

Supriyanto, A.S., Ekowati, V. M and Maghrufuroha ,U. (2020).Do organizational citizenship behavior and work satisfaction mediate the relationship between spiritual leadership and employee performance?, Management Science Letters, 10:1107-1114, doi: 10.5267/j.msl.2019.10.031.

Şehitoğlu, Y and Zehir, C. (2010). Türk kamu kurumlarında çalışan performansının çalışan sessizliği ve örgütsel vatandaşlık bağlamında in Şencan, H. (2005). Sosyal ve davranışsal ölçümlerde güvenilirlik ve geçerlilik, Ankara,43(4): 87 -110.

Şenel, Ş and Alatlı, B. (2014). Lojistik regresyon analizinin kullanıldığı makaleler üzerine bir inceleme, Eğitimde ve Psikolojide Ölçme ve Değerlendirme Dergisi, 5(1): 35-52, ISSN: 1309 - 6575.

Şencan, H. (2005). Güvenilirlik ve geçerlilik. Hüner Şencan.

Tekingündüz, S., Top, M, Tengılımoğlu, D and Karabulut, E.(2015). Effect of organizational trust, job satisfaction, individual variables on the organisational commitment in healthcare services, Total Quality Management, https://doi.org/10.1080/14783363.2015.1099428.

Tokel, C. M. ( 2017). Iş tatmini ve örgütsel vatandaşlık davranışı, Ekonomi, İşletme ve Yönetim Dergisi,1(2): 145-157.

Topçu, M. K., Beğenirbaş, M and Turgut, E.(2017). Örgütsel sinizim, zorunlu örgütsel vatandaşlık davranışları ve iş tatmininin bireysel iş performansına etkilerinin belirlenmesine yönelik imalat sanayinde bir uygulama, Yönetim ve Ekonomi, Manisa Celal Bayer Üniversitesi, 24(2) : 505522, Doi Number:1018657/ yonweek335261.

Turgut, M and Akbolat, M.( 2017). Örgütsel vatandaşık davranışı, örgütsel özdeşleşme ve örgütsel sessizlik ilişkisine yönelik sağlık çalışanları üzerine bir araştırma, Hacettepe Sağlık Idaresi Dergisi, 20, (3): 357-384, https://www.researchgate.net/publication/320161283.

Unaam, A, O., Adim, C, V and Adubasim, E, I.(2018). Employee loyalty and organizational citizienship behaviour in the port harcourt area command of the Niceria police force, International Journal Of Business, Economics And Management,5(6):135-145.

Üngören, E., Arslan, S and Koç, T. S.( 2017). The effect of fatalıstıc belıefs regardıng occupatıonal accıdents on job satısfactıon and organızatıonal trust in hotel industry, Advances in Hospitality and Tourism Research , 5(1): 23-56, (AHTR):s[sp:An International Journal of Akdeniz University Tourism Faculty.

Verburg, R. M., Nienaber, A. M., Weibel,A., Den Hartog, D. N and Ruup, D. E.( 2018).The role of organizational control systems in employees' organizational trust and performance, Outcomes, Group \& Organization Management 43(2): 179-206,DOI: 10.1177/1059601117725191.

Yadav, L. K and Gupta, P. (2017).Procedural justice, job satisfaction and organizational citizenship behaviour: mediating role of organizational trust-Indian tourism industry, Study Management and Labour Studies, 42(3) : 275-292, DOI: 10.1177/0258042X17718738. 
Yanık, O and Naktiyok, A. (2017). Etik (ahlaki) liderliğin çalışanların iş tatminine, örgütsel bağlılığına ve işten ayrılma niyetine etkisinde örgütsel güven ve örgütsel adalet algııının aracı rolü, Bartın Üniversitesi i.i..B.F. Dergisi, 8(15): 297-324.

Yorgancıoğlu Tarcan, .G., Yeşilaydın, G and Karahan, A.(2019). Örgütsel bağlılık ve örgütsel vatandaşlık davranışının incelenmesi: sağlık çalışanları üzerine bir araştırma, Hacettepe Sağlık İdaresi Dergisi, 22(1) S: 157-180, https://dergipark.org.tr/en/download/article-file/670542

Yausef, D. A. (2017). Organizational commitment, job satisfaction and attitudes toward organizational change: a study in the local government, International Journal of Public Administration, 40(1):77-88.

Yıldız, D and Uzunsakal, E. (2018). Alan araştırmalarında güvenilirlik testlerinin karşılaştırılması ve tarımsal veriler üzerine bir uygulama, Uygulamalı Sosyal Bilimler Dergisi, 1:15-28.

Yıldı, H.(2019) The interactive effect of positive psychological capital and organizational trust on organizational citizenship behavior, Original Research, SAGE Open July-September 2019: 1-15 https://doi.org/10.1177/2158244019862661

Yıldız, H .( 2015). Pozitif psikolojik sermaye, örgütsel güven ve örgütsel vatandaşlık,davranışı arasındaki ilişkinin incelenmesi, doktora tezi, Balıkesir Üniversitesi Sosyal Bilimler Enstitüsü, Balıkesir.

Yıldız, S.(2014). Örgütsel adaletin örgütsel vatandaşlık davranışına etkisinde iş tatmininin aracı rolü, Ege Akademik Bakış / Ege Academıc Revıew, Cilt: 14(2):199-210.

Yılmaz, V and İlhan Dalbudak,Z. (2018). Aracı değişken etkisinin incelenmesi: yüksek hızlı tren işletmeciliği üzerine bir uygulama, Uluslar arası Yönetim iktisat ve Işletme Dergisi,14(2): 517-534.

Zeffane, R and Melhem, S, J, B. (2017). Trust, job satisfaction, perceived organizational performance and turnover intention public-private sector comparison in the United Arab Emirates, Employes Relations, 39(7): 1148-1167, https://doi.org/10.1108/ER-06-2017-0135.

Zengin, Y. and Kaygın, E. (2019). Örgüt kültürünün personel güçlendirmeyle ilişkisi: Şanlıurfa'da bir araştırma, Elektronik Sosyal Bilimler Dergisi, Electronic Journal of Social Sciences, 18(70): 903-928, https://doi.org/10.17755/esosder.480286.

\section{Appendix-1: Demographics Findings}

\begin{tabular}{|c|c|c|}
\hline \multicolumn{3}{|c|}{ Demographics Findings } \\
\hline \multirow{3}{*}{$\begin{array}{c}\text { Profession } \\
\text { Administrative staff } \\
\text { Doctor }\end{array}$} & Frequency & Percentage \% \\
\hline & 143 & 15,1 \\
\hline & 100 & 10,6 \\
\hline \multirow{2}{*}{$\begin{array}{c}\text { Patient caregiver } \\
\text { Nurse }\end{array}$} & 144 & 15,2 \\
\hline & 315 & 33,3 \\
\hline \multirow{2}{*}{$\begin{array}{l}\text { Health Technician } \\
\text { Technical Services }\end{array}$} & 107 & 11,3 \\
\hline & 27 & 2,9 \\
\hline \multirow{2}{*}{$\begin{array}{l}\text { Another } \\
\text { TOTAL }\end{array}$} & 109 & 11,6 \\
\hline & 945 & 100 \\
\hline \multirow{5}{*}{$\begin{array}{l}\text { Department worked } \\
\text { Internal Sciences } \\
\text { Surgical Sciences } \\
\text { Basic Sciences } \\
\text { TOTAL }\end{array}$} & Frequency & Percentage \% \\
\hline & 317 & 33,5 \\
\hline & 340 & 36,0 \\
\hline & 288 & 30,5 \\
\hline & 945 & 100 \\
\hline \multirow{7}{*}{$\begin{array}{c}\text { Age } \\
19 \text { and under age } \\
20-29 \\
30-39 \\
40-49 \\
50 \text { and over age } \\
\text { TOTAL }\end{array}$} & Frequency & Percentage \% \\
\hline & 1 & 0,1 \\
\hline & 192 & 20,3 \\
\hline & 363 & 38,4 \\
\hline & 278 & 29,4 \\
\hline & 111 & 11,8 \\
\hline & 945 & 100 \\
\hline \multirow{3}{*}{$\begin{array}{l}\text { Gender } \\
\text { Woman } \\
\text { Man }\end{array}$} & Frequency & Percentage $\%$ \\
\hline & 540 & 57,1 \\
\hline & 405 & 42,9 \\
\hline
\end{tabular}




\begin{tabular}{|c|c|c|}
\hline TOTAL & 945 & 100 \\
\hline \multirow{4}{*}{$\begin{array}{l}\text { Condition } \\
\text { Married } \\
\text { Single } \\
\text { TOTAL }\end{array}$} & Frequency & Percentage \% \\
\hline & 600 & 63,5 \\
\hline & 345 & 36,5 \\
\hline & 945 & 100 \\
\hline \multirow{8}{*}{$\begin{array}{c}\text { Educational Status } \\
\text { Primary School } \\
\text { High School } \\
\text { Associate Degree } \\
\text { License } \\
\text { Post graduate } \\
\text { Doctoral } \\
\text { TOTAL }\end{array}$} & Frequency & Percentage \% \\
\hline & 82 & 8,7 \\
\hline & 175 & 18,5 \\
\hline & 178 & 18,8 \\
\hline & 289 & 30,6 \\
\hline & 124 & 13,1 \\
\hline & 97 & 10,3 \\
\hline & 945 & 100 \\
\hline \multirow{5}{*}{$\begin{array}{c}\text { Total Working Year } \\
1-5 \\
6-10 \\
11-15 \\
16-20\end{array}$} & Frequency & Percentage \% \\
\hline & 160 & 16,9 \\
\hline & 200 & 21,2 \\
\hline & 149 & 15,8 \\
\hline & 169 & 17,9 \\
\hline \multirow{4}{*}{$\begin{array}{c}21-25 \\
25-30 \\
31 \text { and over } \\
\text { TOTAL }\end{array}$} & 122 & 12,9 \\
\hline & 91 & 9,6 \\
\hline & 54 & 5,7 \\
\hline & 945 & 100 \\
\hline
\end{tabular}

\section{Appendix 2: Exploratory Factor Analysis}

\begin{tabular}{|c|c|c|c|c|c|c|c|c|}
\hline 운 & 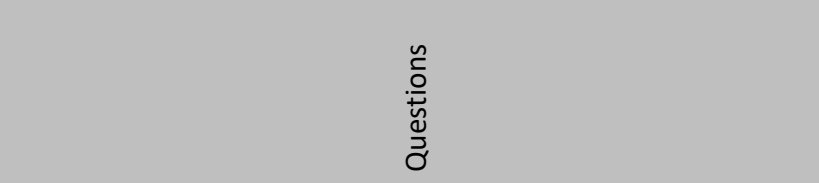 & 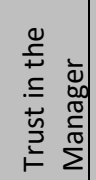 & 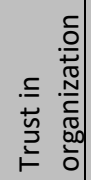 & 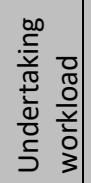 & 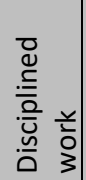 & 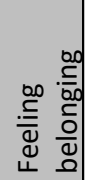 & 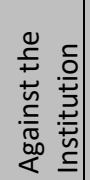 & 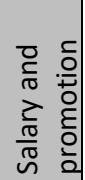 \\
\hline 1 & $\begin{array}{l}\text { It is the degree of my confidence that my manager is } \\
\text { technically adequate on the critical principles in his job. }\end{array}$ & ,833 & & & & & & \\
\hline 2 & $\begin{array}{l}\text { It is the degree of confidence ... that my manager will make the } \\
\text { right decisions about his job. }\end{array}$ & ,823 & & & & & & \\
\hline 3 & My confidence that my manager will not leave his postdegree & ,568 & & & & & & \\
\hline 4 & $\begin{array}{l}\text { It's the degree of confidence that my manager understands his } \\
\text { job at an acceptable level. }\end{array}$ & ,839 & & & & & & \\
\hline 5 & $\begin{array}{l}\text { It is the extent of my confidence that my manager can do his } \\
\text { job appropriately }\end{array}$ & ,848 & & & & & & \\
\hline 6 & $\begin{array}{l}\text { When my manager tells me something, it is the degree of my } \\
\text { confidence that what he says is true. }\end{array}$ & 803 & & & & & & \\
\hline 7 & $\begin{array}{l}\text { It is the degree of my confidence that my manager will do his } \\
\text { job smoothly. }\end{array}$ & 832 & & & & & & \\
\hline 8 & $\begin{array}{l}\text { It is the degree of my confidence that my manager will do his } \\
\text { job carefully }\end{array}$ & 813 & & & & & & \\
\hline 9 & $\begin{array}{l}\text { It is the degree of my confidence that I will be treated fairly in } \\
\text { this institution }\end{array}$ & & 712 & & & & & \\
\hline 10 & $\begin{array}{l}\text { This is the degree of trust I have between managers and } \\
\text { employees in this institution. }\end{array}$ & & ,788 & & & & & \\
\hline
\end{tabular}




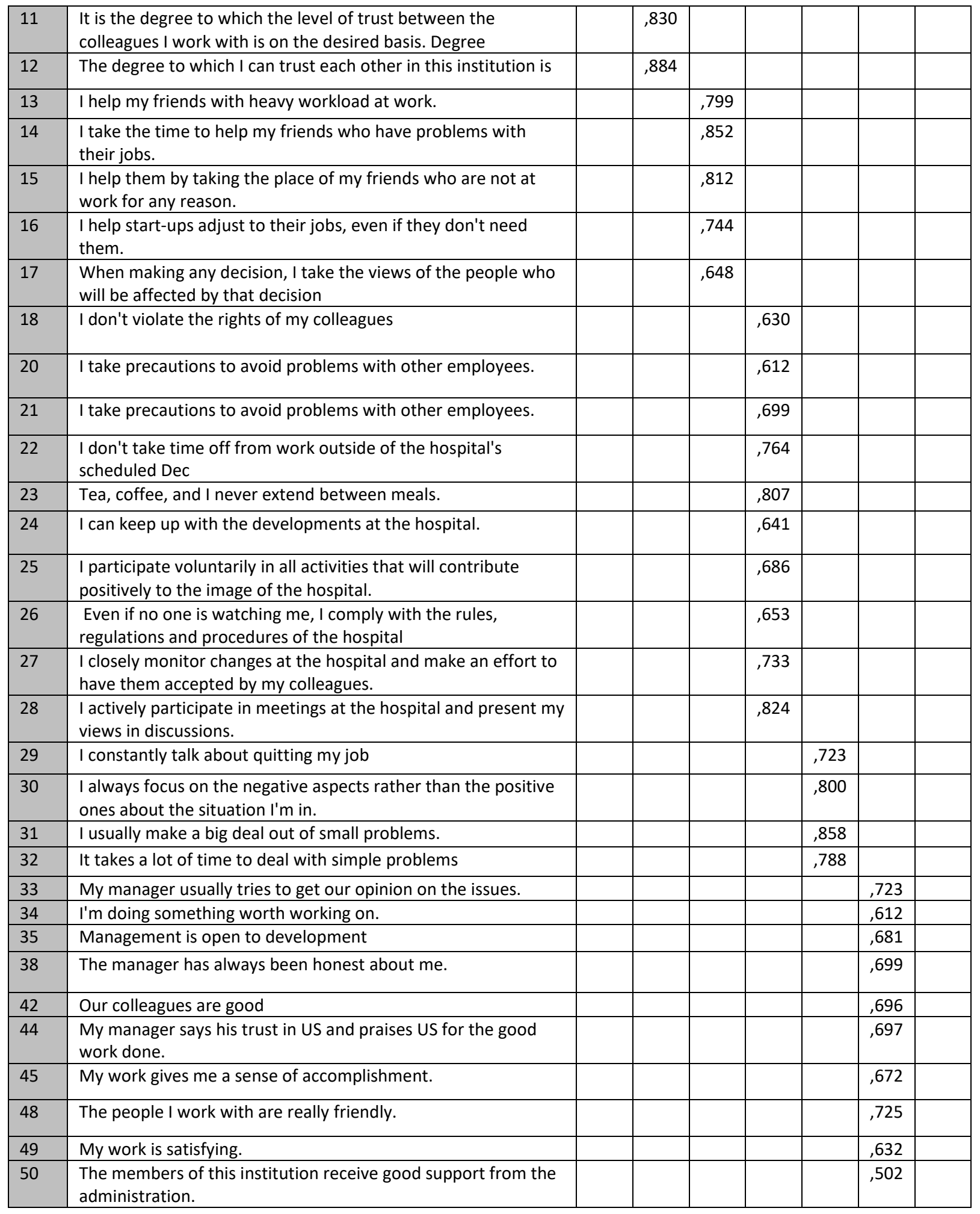




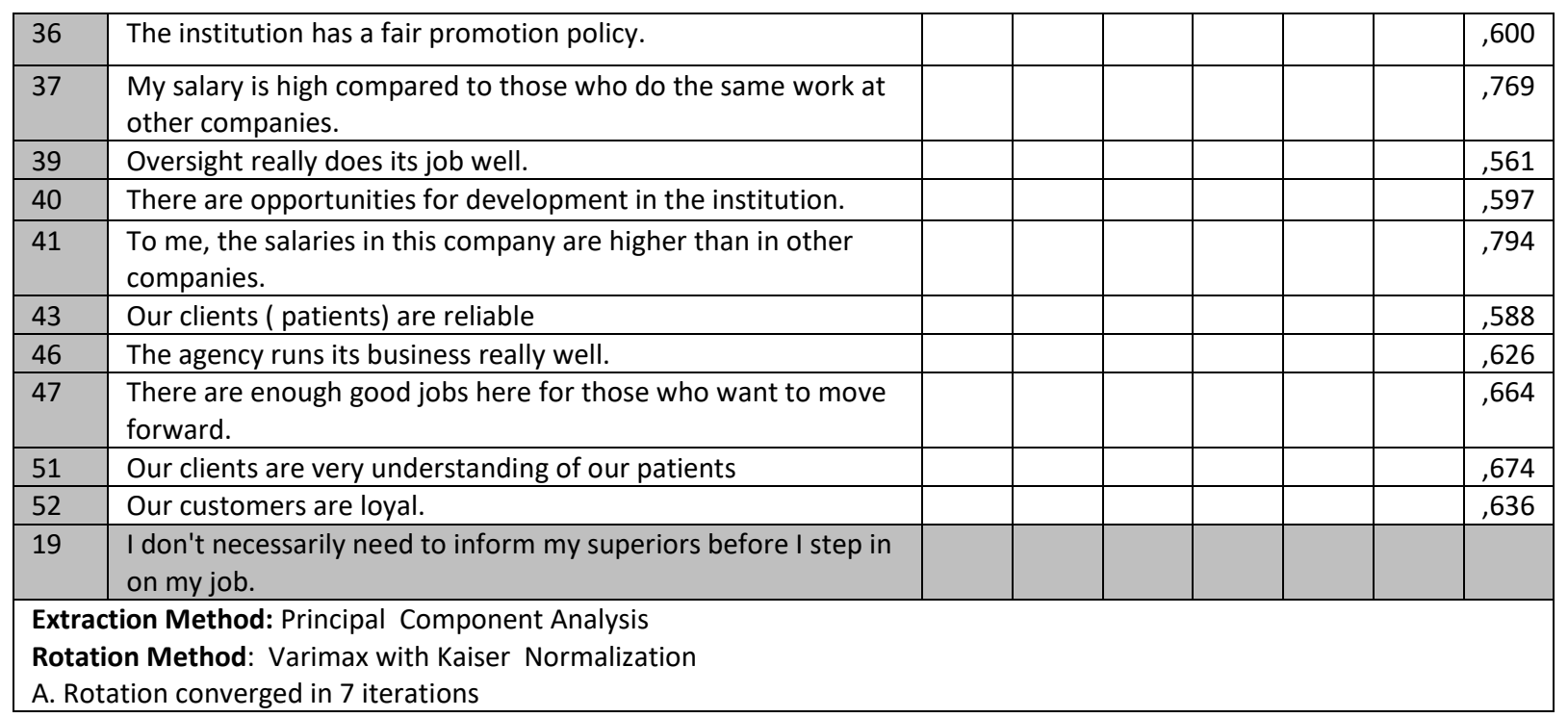

